(C) М.Г. Гончар, О.В. Пиптюк, Я.М. Кучірка, 2018

УДК 616.362-007.21-07-089

\title{
До питання про синдром Міріззі
}

\author{
М.Г. Гончар, О.В. Пиптюк, Я.М. Кучірка
}

Івано-Франківський національний медичний університет, кафедра хірургї стоматологічного факультету, Івано-Франківськ

\section{Реферат}

Синдром Міріззі ми розуміємо як наслідок калькульозного холециститу, при якому конкремент значних розмірів мігрує з жовчного міхура в загальну печінкову або жовчну протоки. При цьому утворюється холецисто-біліарна нориця. Діагностика цієї патології в доопераційному періоді стала можливою з появою ендоскопічних технологій і в даний час, при хронічному перебігу захворювання, вона дає позитивний результат у 50\% випадків. Залишаються дискутабельними питання етіології і класифікації синдрому Міріззі.

За останні 15 років у клініці було виконано 3050 холецистектомій з причини гострого калькульозного холециститу. У 11 пацієнтів виявлено синдром Міріззі. Лапаротомічно прооперовано 10 і лапароскопчно - 1. Усі хворі виписані додому.

Наші спостереження показали, що першопричиною розвитку синдрому Міріззі є функціональні біліарні розлади (дискінезія позапечінкових жовчовивідних шляхів по гіпотонічному типу). Послідовність розвитку даного синдрому може виглядати таким чином: утворення конкрементів; розвиток жовчокам'яної хвороби. Конкремент, який знаходиться в шийці жовчного міхура або в кишені Гартмана тисне на гепатикохоледох, звужуючи його просвіт, що сприяє розвитку запального процесу. Під тиском конкрементів виникає некроз прилягаючих органів з утворенням нориці. Остання збільшується в розмірах і конкремент поступово провалюється в гепатикохоледох, перекриваючи його просвіт.

Існуючі класифікації синдрому Міріззі або достатньо громіздкі для користування, або подібні між собою і відображають етапи міграції конкрементів із жовчного міхура в гепатикохоледох.

При лікуванні синдрому, після зашивання нориці, необхідним є дренування. Ми віддаємо перевагу внутрішнім дренажам.

Ключові слова: синдром Міріззі, УЗД, ЕРХПГ, класифікація, лікування

The Question of Mirizzi's Syndrome

Honchar M.H., Pyptiuk O.V., Kuchirka Ya.M.

Ivano-Frankivsk National Medical University, Department of Surgery, Faculty of Dentistry

Abstract

Mirizzi's syndrome develops secondary to calculous cholecystitis when a concretion of considerable size migrates from the gallbladder to the common hepatic or biliary duct. This produces a cholecysto-biliary fistula. Diagnosis of this pathology in the preoperative period has become possible due to the development of endoscopic techniques; thus, nowadays, it gives a positive result in $50 \%$ of cases in a chronic course of the disease. Nevertheless, the questions of etiology and classification of Mirizzi's syndrome remain quite disputable.

Over the past 15 years, 3,050 cholecystectomies have been performed in our clinic due to acute calculous cholecystitis. Mirizzi's syndrome was detected in 11 patients. 10 patients were operated laparotomically and 1 patient laparoscopically. All patients were discharged from the hospital.

Our observations have shown that the root cause of Mirizzi's syndrome development is a functional biliary disorder (hypotonic extrahepatic biliary dyskinesia). This syndrome development may follow the following pattern: concretion formation - cholelithiasis development. The concretion located in the gallbladder neck or in the Hartmann pouch puts pressure on ductus choledochus thus narrowing its lumen and contributing to the inflammatory process development. Under the pressure of concretions, adjacent organs necrosis develops and a fistula is formed. The latter increases in size and the concretion gradually falls into the choledoch duct thus occluding its lumen.

The existing classifications of Mirizzi's syndrome are either rather cumbersome for everyday use or very similar and reflect the stages of migration of concretions from the gallbladder to ductus choledochus.

While managing the syndrome, having sutured the fistula it is necessary to drain it. We give preference to internal drainage.

Key words: Mirizzi's syndrome, ultrasound diagnosis, endoscopic retrograde cholangiopancreatography, classification, treatment

Уперше Н. Kehr в 1905 році і Ruge в 1908 році описали обструкцію загальної печінкової протоки, зумовленої конкрементом міхурової протоки або запальним процесом в ділянці шийки жовного міхура і гепатодуоденальної зв'язки. Холецистохоледохеальна нориця була описана C. Puestov, в 1942 році. Але це була демонстрація поодиноких випадків.
У 1931 році аргентинський хірург Pablo Luis Mirissi виконав першу інтраопераційну холангіографію, а в 1948 році, вже будучи професором, в своїй публікації «Syndrom del conducto hepatico» описав механізм, який забезпечує функцію руху жовчі по позапечінкових жовчних протоках і синдром, який розвивається внаслідок порушення цього механізму. Причинами останнього Міріззі 
вважав по-перше, функціональний компонент, а саме - спазм міхурової протоки за рахунок наявності циркулярних і спіральних волокон, і подруге, анатомічними особливостями, які викликають розвиток рубцевого процесу: аномальне розташування міхурової артерії, дистопованої кишені Гартмана, наявність конкремента на виході $з$ жовчного міхура або його обструкція.

У 1952 році Міріззі надрукував статтю про 4 спостереження внутрішніх спонтанних біліобіліарних нориць. В цій роботі він висловив думку про можливість зв'язку вказаної нориці з анатомічними i функціональними змінами в жовчних шляхах і те, що конкременти стають найбільш частою причиною цього синдрому.

Якщо взяти роздуми самого Міріззі про розвиток описаного ним синдрому, то виникає дуже складна схема патогенезу, яка не вкладається в якусь одну рамку патології (функціональний фактор, анатомічні особливості, жовчнокам'яна хвороба). Через це до сьогоднішнього дня ведеться дискусія між різними хірургічними школами, що таке синдром Міріззі?

Найбільш розгорнуте трактування вказаного синдрому передбачає ототожнення патології зі стенозом загальної печінкової протоки або зони кишені Гартмана 3 конкрементом, які супроводжуються запальним процесом в жовчному міхурі, холангітом і жовтяницею.

Більш суттєво різняться думки тих авторів, які вважають, що морфологічною основою синдрому $\epsilon$ тільки міхурово-холедохеальна нориця. Але і тут виникають різні трактування, як це відображено в класифікації М. В. Corlette, H. Bismuth [1], які передбачають розподіл біліо-біліарних нориць на два види, в залежності від місця розташування нориці - в ділянці загальної печінкової чи загальної жовчної проток [2,11]. Інші дослідники вважають, що для синдрому Міріззі характерно звуження гепатікохоледоха і наявність холецисто-холедохеальної нориці.

В останні роки з'явилося багато публікацій, в яких дослідники висловлюють думку про існування двох форм синдрому Міріззі: перша - гостра, 3 ознаками звуження гепатикохоледоха i друга хронічна, з наявністю нориці між гепатикохоледохом і жовчевим міхуром. Дехто з авторів і сам Мiріззі розглядають як один процес, зумовлений міграцією конкрементів з жовчного міхура в холедох. Звідси витікає, що синдром є ускладненням жовчнокам'яної хвороби [24].

Багато науковців показують, що крім морфологічних змін, велике значення у визначенні синдрому має з'ясування природи його появи. I тут немає спільної думки. У одних повідомленнях висловлюється думка, що причиною звуження просвіту гепатокохоледоха є спастичні скорочення їх циркулярних м'язів, внаслідок перистальтики, стисненням аномально розташованої міхурової протоки пухлиною, спайками, лімфатичними вузлами, гострим холециститом, наявністю конкремента в міхуровій протоці або кишені Гартмана. У міру вивчення цієї проблеми більшість причин названих авторів були не підтверджені [19].

В роботі М. Музашвілі [11] дано класичний опис синдрому Міріззі, який передбачає патогенез його розвитку: 1) близьке і паралельне розташування міхурової протоки i гепатикохоледоха; 2) наявність конкремента в міхуровій протоці, в шийці жовчного міхура або в кишені Гартмана; 3) обструктивний процес в ділянці загальної печінкової протоки, який зумовлений фіксованим конкрементом в міхуровій протоці чи запальним процесом навколо нього; 4) наявність механічної жовтяниці з ознаками холангіту або без нього.

Незважаючи на численні спроби стандартизувати хірургічне лікування синдрому Міріззі, до сьогоднішнього дня консенсуса так і не було досягнуто і жоден із запропонованих алгоритмів не був прийнятий світовим хірургічним співтовариством. Основними причинами цього є рідкість даної патології та її виявлення під час операції. Ці причини виключають розробку та виконання контрольованих рандомізованих досліджень для перевірки запропонованих хірургічних підходів. Немає публікацій про довготермінові спостереження за результатами хірургічного лікування будь-якого типу синдрому Міріззі.

За останні 15 років у клініці було виконано 3050 холецистектомій 3 причини калькульозного холециститу. Вік хворих коливався від 34 до 85 років. Серед пацієнтів переважали жінки (73,2 \%). Всім хворим при госпіталізації проводили загальноклінічні та біохімічні обстеження, УЗД органів черевної порожнини, ФГДС. Синдром Міріззі був виявлений інтаопераційно у $11(2,77 \%)$ хворих. В 10 випадках була проведена лапаротомія, в 1 лапароскопічне ушивання гепатіко-холедоха. Зовнішнє дренування холедоха проведено 7 пацієнтам, у 3 випадках був використаний внутрішній дренаж. Летальних наслідків не було. Термін перебування хворих у стаціонарі тривав 18-27 діб.

Наші спостереження збігаються 3 думкою і інших дослідників. Так, Claudel T. et al. [16] вважають, що термін «дискінезія жовчного міхура» не $\epsilon$ повним синонімом дискінезії жовчовивідних шляхів, оскільки відображає вже сучасну класифікацію функціональних розладів гепатобіліарної системи. В даний час усі варіанти функціонального порушення відтоку жовчі у дванадцятипалу кишку, що виникають внаслідок некоординованого скорочення протоків, жовчного міхура та сфінктерів, об’єднюють під терміном «функціональні біліарні розлади» і саме цей термін можна вважати синонімом «дискінезії жовчовивідних шляхів».

Для утворення конкрементів необхідна наявність таких чинників; секреція «літогенної жовчі» печінкою, наявність ядер для подальшої кристалізації, застою жовчі у жовчному міхурі, що забезпечує умови для зростання i злиття кристалів 3 
утворенням конкрементів у здоровому жовчному міхурі. Формуванню конкрементів перешкоджає лужне середовище жовчі, швидке видалення кристалів холестерину і скупчень слизу під час спорожнення міхура не менше 3 разів на добу. Зниження моторики жовчного міхура сприяє утворенню жовчних каменів.

На думку Di Ciaula et all. [17], Cotton P.B. et all. [19] етіологія функціонального розладу жовчевого міхура $\epsilon$ ще недостатньо вивченою, але більшістю дослідників вона загалом розглядається як порушення моторики жовчного міхура. Це може виникнути внаслідок первинного порушення обміну речовин або первинного порушення моторики при відсутності будь-яких аномалій складу жовчі.

Тому ми дотримуємося думки, що першопричиною розвитку синдрому Міріззі $є$ функціональні біліарні розлади (дискінезія жовчовивідних шляхів по гіпотонічному типу). Послідовність розвитку даного синдрому, на наш погляд, може виглядати таким чином. Утворення конкрементів, розвиток жовчно-кам'яної хвороби, внаслідок атонії жовчевого міхура він прилягає до гепатикохоледоха; конкременти, які знаходяться в шийці жовчного міхура або в кишені Гартмана тиснуть на гепатикохоледох, звужуючи його просвіт і розвивається хронічний запальний процес; під тиском конкрементів виникає некроз прилягаючих органів 3 утворенням нориці; остання збільшується в розміpax i конкремент поступово провалюється в гепатокохоледох, перекриваючи його просвіт.

Припустимо, що ми 3'ясували етіопатогенез синдрому Міріззі. Наступний етап - це його діагностика і лікування, особливо хірургічне. На думку багатьох хірургів, у вирішенні цього питання може допомогти класифікація синдрому. Важливість і кінцева мета усіх систем класифікації синдрому Міріззі полягає в тому, щоб дозволити хірургу адаптувати хірургічний підхід до окремого випадку. Ця ціль не була повністю виконана існуючими опублікованими класифікаціями. Крім того, визнання холецисто-інтестінальних фістул, пов'язаних з синдромом Міріззі і відповідне додавання нової класифікації синдрому Міріззі до класичної класифікації А. Csendes [22] ще більше ускладнило правильний діагноз, класифікацію та лікування даних пацієнтів.

Перша належить самому Міріззі і базується на локалізації біліо-біліарних нориць в залежності від їх розташування. Вище впадіння міхурової протоки в холедох, на рівні і нижче місця впадіння. Тяжко сказати, що вона дає практичному хірургові.

Друга класифікація належить Mc. Sherri et al. [21] і складається з 2-х пунктів; перший - стиснення холедоха конкрементом, що приводить до його звуження і розвитку механічної жовтяниці; другий - утворення біліо-біліарної нориці з некрозом стінки холедоха.Ця класифікація більш практична.

A. Morelli et al. [24], Э.Н. Гальперин и соавт. [13] запропонували класифікацію подібну до по- передньої. Вони виділяють дві форми: гостру зі стисненням холедоха і хронічну - 3 міхуровохоледохеальною норицею. Класифікації Т. Nagakawa et al. [23], О. J. Shan et al. [15] подібні до попередніх і грунтуються на шляхах міграції конкремента. В.С. Савельев, В.И. Ревякин [12] розробили класифікацію, яка розкриває суть патологічного процесу. Вона надзвичайно громіздка і тому тяжка в практичному користуванні.

В останній час широкого застосування набула класифікація A. Csendes et al. [22]. Автори провели ретро- і проспективний аналіз 219 пацієнтів на синдром Міріззі і виділила 4 анатомічні типи синдрому.

1 тип - стиснення загальної жовчної протоки конкрементом, який локалізується в шийці жовчного міхура, міхуровій протоці або в кишені Гартмана;

2 тип - гепатико-холедохельна біліарна нориця, при якій конкремент на $1 / 3$ перекриває просвіт протоки;

3 тип - гепатико-холедохельна біліарна нориця, при якій конкремент на $2 / 3$ перекриває просвіт протоки;

4 тип - холецистобіліарна нориця 3 пошкодженою печінковою протокою або холедохом по всій окружності.

Якщо уважно подивитися на цю класифікацію, то напрошується висновок, що це не різні типи анатомічного пошкодження, а етапи міграції конкремента в холедох або загальну печінкову протоку. Все залежить від того, на якому етапі міграції хірурги оперували хворого.

Наявність значного числа класифікацій, які в багатьох випадках грунтуються на незначній кількості клінічних спостережень, демонструє неоднозначне трактування як анатомічного розуміння синдрому Міріззі, так і суті патологічного процесу, що лежить в основі даної проблеми. А це, в свою чергу, ускладнює діагностику та вибір хірургічної тактики.

В клінічній картині переважають класичні симптоми тріади Шарко (біль у правому підребер'ї, жовтяниця і підвищення температури тіла, внаслідок наявності холангіту).

Діагностика даної патології базується на «трьох китах» - ретроградна холангіографія, ультрасонографія і комп'ютерна томографія. На превеликий жаль хвороба починається з клініки гострого холециститу і УЗД є підтвердження цього діагнозу. Це не спонукає хірургів на подальше, більш глибоке, обстеження пацієнтів. Вся проблема починається під час операції, коли хірург при лапароскопічній діагностиці, а інколи вже в процесі препарування жовчного міхура зустрічається 3 аномалією анатомічної будови жовчного міхура і його співвідношенні до загальної печінкової протоки або холедоха. В таких випадках оператор вимушений робити інтраопераційну холангіографію i, при необхідності, конверсію $[3,5,6,8]$. 
Сучасні лапароскопічні технології дозволяють лапароскопічно відновити гепатіко-холедох, але в тих випадках, коли розвинутий злуковий процес, виражена значна деформація, яка не дає можливості анатомічно зорієнтуватися в патологічному процесі, конверсія необхідна $[4,9,10,20]$.

Ми неоднозначно підходимо до зовнішнього дренування холедоха за Кером, Вишневським, Піковським після відновлення його будови, а віддаємо перевагу внутрішнім дренажам. Силіконову трубку довжиною $10-15 \mathrm{~cm}$ в холедоху фіксуємо кетгутовим швом і проводимо через сфінктер Одді в дванадцятипалу кишку. Через 6-8 діб він мігрує в кишечник, але цього часу достатньо для загоєння ушитого холедоха. За нашими спостереженнями, перевага внутрішнього дренажа полягає в тому, що він не дає рубцевого звуження протоки, як це спостерігається при зовнішньому дренуванні в місці фіксації на холедоху. Питання це дискутабельне і не можна давати рекомендації іншим хірургам, які $є$ прихильники інших методів дренування [7].

Таким чином, наше бачення етіології і патогенезу розвитку синдрому Міріззі дещо відрізняється від інших, але це не вказує про те, що всі інші дослідники цієї патології не праві. На наш погляд, воно гармонійно пояснює причину каменеутворення i $\epsilon$ предиктором міграції останніх $з$ жовчного міхура в гепатіко-холедох. Що стосується класифікацій, то в своїй переважаючій більшості вони відображають не різні аспекти захворювання, а етапи послідовної міграції конкремента 3 жовчного міхура в холедох.

Висновки. 1. Першопричиною розвитку синдрому Міріззі є розвиток жовчекам'яної хвороби.

2. Одним 3 важливих етіопатогенетичних факторів розвитку синдрому Міріззі при жовчнокам'яної хворобі є дискінезія позапечінкових жовчних проток по гіпотонічному типу.

3. Існуючі класифікації або достатньо громіздкі для користування, або подібні між собою і відображають етапи міграції конкремента 3 жовчного міхура в гепатіко-холедох.

Тому виникає питання: а чи вони потрібні? Можливо достатньо розписати тактику хірурга на різних етапах міграції конкремента і ступені пошкодження гепатіко-холедоха.

Дана публікація не $\epsilon$ кінцевим вирішенням проблеми синдрому Міріззі, а $є$ результатом незначного досвіду авторів в лікуванні цієї патології та індивідуальним баченням етіопатогенезу захворювання.

Інформація про конфлікт інтересів. Автори заявляють про відсутність конфлікту інтересів при виконанні наукового дослідження та підготовці даної статті.

Інформація про фінансування. Автори гарантують, що вони не отримували жодних винагород в будь-якій формі, здатних вплинути на результати роботи.

Особистий внесок кожного автора у виконання роботи:

Гончар М.Г. - розробка концепції і дизайну дослідження;

Пиптюк О.В. -аналіз отриманих даних, редагування;

Кучірка Я.М. - збір матеріалу, підготовка тексту.

\section{Список використаної літератури}

1. Belebekov ZO, Ysmajylov KS, Mamanov NA. Kliniko-patomorfologicheskaja klassifikacija sindroma Mirizzi. Hirurgija. 2013;3(29):38-41. [In Russian].

2. Grejasov VI, Perfil'ev VV, Shepkin SP. Diagnostika i hirurgicheskaja taktika pri sindrome Mirizzi. Hirurgija. 2008;11:31-4. [In Russian].

3. Dutka YR. Osoblyvosti diahnostyky i khirurhichnoho likuvannia khvorykh na syndrom Miritstsi II. Acta Medica Leopoliensia. 2008;1-2:89-91. [In Ukrainian].

4. Kolkin JG, Hacko VV, Dulin AM, et al. Sindrom Mirizzi: diagnostika i hirurgicheskaja taktika. Ukrainskyi Zhurnal Khirurhii. 2012;2(17):115-8. [In Russian].

5. Nychytailo MY, Kondratiuk OP, Lytvynenko OM, et al. Diahnostyka ta khirurhichne likuvannia syndromu Miritstsi. Klinicheskaia khirurgiia. 2000;10:33-35. [In Ukrainian].

6. Tamm TI, Belov SG, Bardjuk AJ, et al. Diagnostika i hirurgicheskaja korrecija sindroma Mirizzi. Ukrainskyi zhurnal khirurhii. 2013;3(22):93-5. [In Russian].

7. Siplivij VA, Evtushenko DV, Petrenko GD et al. Diagnostika i hirurgicheskoe lechenie sindroma Mirizzi. Klinicheskaia khirurgiia. 2016;8:8-11. [In Russian].

8. Hvorostov ED, Grinev RN. Sindrom Mirizzi: diagnostika i hirurgicheskoe lechenie. Vrachebnaja praktika. 2004;6:30-2. [In Russian].

9. Jurchenko VV, Nyzhnik LM, Abzhalov MA, et al. Endohirurgicheskie sposoby lechenija konkrementov zhelchnyh protokov. Vestnik Baltijskogo federal'nogo universiteta im. I.Kanta. 2016;2:23-32. [In Russian] 10. Savelev VS, Revjakin VI. Sindrom Mirizzi. Diagnostika i lechenie. Moscow: Medicina; 2003. 203 p. [In Russian].

11. Galperin EI, Ahaladze GG, Kotovskij AE, et al. Sindrom Mirizzi: osobennosti diagnostiki i lechenija. Annaly hirurgicheskoj gepatologii. 2006;11:7-10. [In Russian]. 
12. Claudel T, Zolner G, Wagner M, Trauner M. Role of nuclear receptors for bile acid metabolism, bile secretion, cholestasis, and gallstone disease. Biochim Biophys Acta. 2011;18(12):867-78.

13. Di Ciaula A, Wang DQ, Portincasa P. An update on the patogenesis of cholesterol gallstone disease. Curr Opin Gastroenterol. 2018 Mar;34(2):71-80. DOI: 10.1097/MOG.0000000000000423.

14. Carr JA, Walis JJ, Brian LJ, Snider DL. The treatment of gallbladder dyskinesia based upon symptoms. Results of a 2-year, prospective, nonrandomized, concurrent cohort study. Surg Laparosc Endosc Percutan Tech. 2009 Jun;19(3):222-6. DOI: 10.1097/SLE.0b013e3181a74690

15. Cotton PB, Elta GH, Carter CR, Pasricha PJ, Corazziari ES. Rome IV. Gallbladder and Sphincter of Oddi Disorders. Gastroenterology. 2016 May; 150(6):1420-9.

16. Le Roux F, Sabbagh C, Robert B, Yzet T, Dugue L, Joly JP, et al. Multidisciplinary management of Mirizzi syndrome with cholecystobiliary fistula. The value of minimally invasive tndoscopic surgery. Hepatobiliary Pancreat Dis Int. 2015;14(5):543-7.

17. Mc Sherry CK, Ferstenberg H, Virshup M. The Mirizzi syndrome. Suggested classification and surgical treatment. Surg. Gastroenterol. 1982;1:219-25.

18. Csendes A, Diaz CJ, Burdiles P., et al. Mirizzi syndrome and cholecystobiliary fistulas. A unifying classification. Br. J. Surg. 1989 Nov;76(11):1139-43.

19. Nagakawa T, Ohta T, Kayahara M, Ueno K, Konishi I, Sanada H, et al. A new classification of Mirizzi syndrome from diagnostic and therapeutic viewpoints. Hepatogastroenterology. 1997 Jan-Feb;44(13):63-7.

20. Beltran MA. Mirizzi syndrome. History, current knowledge and proposal a simplified classification. World J Gastroenterol. 2012 Sep;18(34):4639-50. DOI: 10.3748/wjg.v18.i34.4639

Стаття надійшла до редакції: 7.08.2017 p. 